på dansk videoproduktion, hvorfor er der ingen 'underground'-produktioner osv. Dette er ikke kun et spørgsmål om personlige præferencer, men tillige et spørgsmål om repræsentativitet i eksempelmaterialet. Det virker også underligt når man læser om Art of Noices video: Close to the edit og så opdager, at det ikke er den samme video, som er med $\mathrm{i}$ eksempelmaterialet, selvom den hedder Close to the edit. Sjusket!

Indvendingerne mod bogen går på det principielle plan, hvor Movin og Øberg alt for ukritisk overtager de ureflekterede forestillinger om musikvidecerne, som har floreret $\mathrm{i}$ årevis, og som har været uden teoretisk prægnans. Og her har jeg endog ikke været inde på selve analyserne af videoer, hvor forfatterne falder i samme afgrund som utallige andre fors $\emptyset \mathrm{g}$ på læsning af musikvideoer. Man tror at blot fordi fremstillingerne ofte er fragmentariske, så eksisterer der ingen enhed i musikvideoeme. Men som bla. Peter Larsen har vist, i et af de hidtidige bedste danske fors $\emptyset \mathrm{g}$ p a at forstå musikvideœer: »Hinsides fortællingen« fra 1984 (i tidsskriftet Argos), så skabes der til stadighed sammenhæng $i$ videoerne. Det sker gennem musikken, i sammenstilling og rytme og i recipientens egen fortællende læsning, som fører de forskellige billeder sammen til en ikke alt for urimelig sammenhæng, som det hedder med reference til Freuds drommetydning.

Det virker som om forfatterne mener, at musikvideoeme er gode, hvis de viderebringer et kritisk budskab om vor mediedominerede tilværelse. Men, som David Lynch har sagt, så handler æstetiske frembringelser ikke primært om budskaber - det har man postvæsenet til at viderebringe. Dog skylder jeg nok også forfatterne at citerer et sted, hvor de ikke restløs identificerer sig med en ideologikritisk position. Deres fremstilling holder ikke fast i én mening, men glider hele tiden, som betydningen selv $\mathrm{i}$ det aktuelle. Man kan måske sige, »at musikvideo for nutidens unge rummer et ligeså stort protestpotentiale, som rocken gjorde det for 60'ernes unge, og at den maske netop er udtryk for et oprør imod tresser-generationens rigtige meninger og idealistiske forestillinger om tilværelsen«. Gad vide om forfatterne selv kan se, at de også her foretager en projicering af en tresser-dyd: kritikken og overskridelsen?

\section{Lis Moller}

\section{Dekonstruktion}

Pil Dahlerup: Dekonstruktion. 90'ernes litteraturteori. Gyldendal, 96 s.,1991; Kr. 98,00.

Dekonstruktion. 90'ernes litteraturteori er titlen på Pil Dahlerups præsentation af den litterære dekonstruktion i Gyldendals Intro-serie. Mon det skulle være forlagets marketingafdeling, der står bag denne lidt for smarte undertitel - som ikke bare er et noget tvivlsomt postulat, al den stund at umiddelbare appliceringer af dekonstruktiv teori i læsningen af litterære varker synes at være et overstået kapitel i hjemlandet USA ${ }^{1}$, men som tillige synes at harmonere dårligt med forfatterens mere forbeholdne syn på dekonstruktion. Kritisk sans, læs: almindelig sund fornuft, er den bedste 
vejleder i teorijunglen; den har man brug for, når det drejer sig om dekonstruktion, mener Dahlerup, som understreger, at hun ikke er »ubetinget tilhænger« (6) af denne retning, men fastholder det meste af det, hun har lært af nykritikken og strukturalismen.

Det er den litterære udformning af dekonstruktionen - dens litteraturteoretiske implikationer og brugbarhed indenfor litteraturkritikken - der er bogens emne. Dahlerup starter med at konstatere, at dekonstruktion som litteraturteori står i modsætning til strukturalismen. Mens strukturalisterne leder efter tekstens meningsbærende strukturer, søger dekonstruktivisterne efter de elementer i teksten, der får strukturerne til at bryde sammen indefra. Bevægelsen fra strukturalisme til dekonstruktion styrer fremstillingen, der er i fire selvstæendige kapitler diskuterer »fire væsentlige skred (6) i tekstbegrebet: »Fra cn egenskab hos teksten til en erfaring hos læseren《 (om læseren), »Fra en modsætning imellem til en modsætning $i \ll$ (om kritikken af strukturbegrebet), »Fra $h v a d$ det betyder til hvordan det betyder « (om dekonstruktion som retorisk lixsning) og endelig »Fra kvinde til køn« (om feministisk dekonstruktion). De fire kapitler er forsynet med korte litteraturanalyser, der skal illustrere, hvordan man i praksis kan anvende den behandlede teori.

Det har tydeligvis været ambitionen at lave en brugsbog snarere end en avanceret indføring. Som teksten på omslaget lover, er bogen »letlæst $\ll$. Som en første introduktion til dekonstruktionen har Dekonstruktion. 90' ernes litteraturteori således oplagte kvaliteter. Desværre har bogen også mangler. Forfatteren bemarker selv, at hendes oversigt ikke er udt $\varnothing$ mmende. Naturligvis ikke. En 90 siders gennemgang af den litterære dekonstruktion, beregnet på den uindviede læser, må nødvendigvis være selektiv og operere med forenklinger. Problemet er således ikke, at fremstillingen ikke kan få det hele med. Mine forbehold vedrører selve det begreb om dekonstruktion, som bogen formidler. For Dahlerup betyder dekonstruktion mere abenhed, pluralisme og større respekt for teksten som kunst. Det er altsammen meget sympatisk, men også temmelig tamt. I Dahlerups pædagogiske applicering bliver dekonstruktion så spiselig, at man har noget svært ved at få øje på, at den (som bagsideteksten lover det) skulle være en radikal teori, »der vil vende op og ned på vestlig tænkning og på hele litteraturbegrebet«.

Ikke overraskende er det i kapitlet om strukturbegrebet (kapitel 2), at modsætningsforholdet mellem strukturalisme og dekonstruktion træder klarest frem. Dahlerup tager udgangspunkt i Saussures strukturelle lingvistik og Greimas' definition af struktur som en autonom enhed af interne relationer, der er opbygget i hierarkier. Heroverfor sættes Jacques Derridas påpegning af, at alle strukturer bryder sammen indefra, fordi enhver struktur for overhovedet at oprettes må udgrænse de elementer, der modsiger systemet. Man kunne måske her forvente, at Dahlerup ville præsentere Derridas kritik af Levi-Strauss i "Structure, Sign and Play in the Discourse of the Human Sciences " (denne tekst, der blev fremlagt ved en konference i USA i 1966, markerer dekonstruktionens begyndelse i Amerika). Dahlerup valger imidlertid at tage fat et andet sted: Derridas kritiske reception af Saussures tegnbegreb. I følge Derrida 
opererer Saussure med en $\gg$ transcendental signifié«, dvs. en signifié der ikke viser hen til nogen signifiant, men fungerer som sidste absolut led, der forankrer systemet. Derrida benægter muligheden af et sådant sidste led, idet hàn hævder, at enhver signifié også fungerer som signifiant. Når signifié og signifiant kan skifte plads, er strukturen ikke fast men flydende - hvilket hos Derrida markeres med begrebet »differance « (forskel og udsættelse), der, som han understreger det, er uforeneligt med det statiske og synkrone i begrebet »struktur«.

Imidlertid er det først og fremmest det litterære, der interesserer Dahlerup: den litterære strukturalisme og den litterære dekonstruktion. Man kan mene, at Dahlerup foretager en noget voldsom beskæring af den litterære strukturalisme - hos hende betyder strukturel analyse kort og godt: modsætningsanalyse. Men, okay, reduktionen er ikke uden pædagogisk effekt. Den kortfattede gennemgang af den litterære strukturalisme i 60'eme ledsages af en lille analyse, efter devisen »find tekstens grundlæggende modsætningspar«, af Ludvig Bødtchers digt »Ved et Tab«. Senere i kapitlet vender Dahlerup tilbage til analysen af Bødtchers digt, der nu korrigeres gennem en slags dekonstruktiv læsning. Den dekonstruktive analyse fremtræder her som et kritisk supplement til modsærningsanalysen.

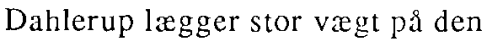
pædagogiske formidling af sit stof. Det $k$ an derfor undre, at hun ikke henviser til eksisterende danske oversættelser af de diskuterede tekster. Hvorfor henvise til en engelsk oversættelse af Saussure, når der findes en udmærket dansk oversattelse $\mathrm{i}$ antologien Strukturalisme (som i øvrigt også indeholder Kristevas interview med Derrida om Saussures tegnbegreb)? Men det er selvfølgelig en detalje. Mere bcklageligt er det, at Dahlerup overser en række oplagte pointer i de behandlede tekster, f.eks. i Barbara Johnsons analyse af Billy Budd. Det er fra Johnson, at Dahlerup henter formuleringen "fra en modsætning imellem til en modsætning $i \ll$, der sammenfatter skredet fra strukturel modsætningsanalyse til dekonstruktiv læsning. Billy $B u d d$-analysen er i sig selv en brilliant demonstration af skredet fra »imellem《 til $\gg \mathrm{i} \ll$, som bedre end den ansatsvise dekonstruktion af $B \emptyset$ dtcher kunne illustrere strukturens sammenbrud indefra. Desværre går dette aspekt tabt i Dahlerups gennemgang, som munder ud i den noget vage konstatering, at $\gg$ Barbara Johnson med sin dekonstruktion vil vise, at en simpel tekst er sammensat" (43).

Kapitlet om læseren er nok bogens svageste afsnit. Det drejer sig som sagt om bevægelsen fra tekst til Læser: I følge strukturalismen opstår tekstens betydning gennem relationerne mellem tekstens elementer. Heroverfor hævder Reider-Response kritikken (som her henregnes til dekonstruktionen), at betydningen skabes gennem læseprocessen, i samspillet mellem tekst og læser. Men, som Dahlerup bemærker, er der mange varianter af den nye læser-orienterede kritik. Begrebet læser kan betyde mange ting, selv indenfor Reader-Response kritikken. En læser kan være den instans, der realiserer teksten, idet han/ hun udfylder de »huller «, der er den litterære teksts konstitutive træk (Wolfgang Iser). Eller læseren kan være et konkret psykologisk individ, der investerer sine egne private fantasmer $\mathrm{i}$ læs- 
ningen, sådan som det er tilfældet hos den psykoanalytiske kritiker Norman Holland. Men en læser kan også være et tekstelement, fortsætter Dahlerup og nævner her som et eksempel Gerald Prince's $» I n t r o d u c t i o n$ to the Study of the Narratee «. I gennemgangen af Prince sløres den forestilling om et modsætningsforhold mellem dekonstruktion og strukturalisme, som er bogens bærende ide, for Princes begreb om »the narratee « lader sig uden besvær placere indenfor rammerne af den strukturelle narratologi.

Man kan vanskeligt være uenig med Dahlerup i, at den nyere interesse for læseren og læsningen og det skred i tekstbegrcbet, der hænger sammen med denne interesse, er relevant for forstâelsen af den litterære dekonstruktion. Så kan man diskutere, om det er rimeligt at gøre dekonstruktionen så elastisk, at den kan rumme den i sig selv heterogene gruppe af teoretikere og kritikere, der prasenteres under overskriften ReaderResponse Criticism: Stanley Fish, Michael Riffaterre, Hans Robert Jauss, Umberto Eco foruden de ovennæunte. Mere afgørende er det imidlertid, at Dahlerup aldrig kommer langt nok ind $i$ diskussionen af lesningens problem, som står så centralt $\mathrm{i}$ den amerikanske dekonstruktion. I sin disponering af stoffet har Dahlerup tydeligvis ladet sig inspirere af Jonathan Cullers $O n D e-$ construction. Theory and Criticism after Structuralism, hvis indledningskipitel netop handler om læser-orienterede teorier. Men hvor Dahlerup giver en kommenteret præsentation af de forskellige Reader-Response teorier og dermed betragter spørgsmålet om dekonstruktiv læsning som uddebatteret, så lader Culler diskussionen af reader-response danne afsæt for gennemgangen af dekonstruktionen. Dahlerup stopper, hvor Culler begynder, og det er en skam.

Jeg mener således, det er en klar mangel ved fremstillingen som sådan, at Dahlerup aldrig når frem til det specifikt dekonstruktive begreb om lasning dekonstruktionens snegative hermeneutik", om man vil - som indebærer forestillingen om »ulæselighed « (»unreadability«). Ulæselighed - siger Paul de Man ved en af de få lejligheder, hvor han har bestræbt sig p\&̊ at udtrykkke sig pædagogisk - betyder at teksten producerer læsninger, der er indbyrdes uforenelige. Det vil sige, at man fra en given tekst kan udlede en læsning, der er helt i overensstemmelse med tekstens figuration, men samtidig kan man også udlede en anden læsning, der en semantisk uforenelig med den første. De to læsninger er fundamentalt modstridende, eftersom de kin reduceres til udsagn, der ikke bare er uforenelige, men opløser hinanden. ${ }^{2}$ Teksten er ulæselig i den forstand, at den giver anledning til modstridende fortolkninger, men intet grundlag for at vælge imellem dem. I artiklen "Semiology and Rhetoric « (som Dahlerup behandler i kapitel 3) forbinder de Man det tolkningsdilemma, teksten giver anledning til, med sprogets retoriske potentiale. Retorikken suspenderer logikken og skaber ubestemmelighed.

Dahlerup understreger i sin konklusion, at den dekonstruktive læsning risikerer at havne i »tomt ordg $\emptyset$ gleri« (91), hvorved den mister sin berettigelse. Kritikken er ikke helt uberettiget $\mathbf{i}$ forbindelse med teorien om ubestemmelighed. Doktrinen om tekstens ulæselighed - der i den amerikanske dekonstruktions konsolideringsfase i 80'erne kom til at 
fremstå som den dekonstruktive kritiks slagord og varemærke - ender som en tom frase, når den »bevises« $\mathrm{i}$ analyse efter analyse. $P a ̊$ det seneste har der da også lydt mangc kritiske røster. Dekonstruktive læsninger er med årene blevet forstemmende forudsigelige, hxvdes det; den blotte påvisning af aporier kan ikke længere være analysens endemål. Imidlertid pointerer de selvsamme kritikere, er der ikke er nogen vej tilbage til et præ-dekonstruktivt standpunkt. Det drejer sig om at komme videre, ikke om at vende tilbage. Teksten har mistet sin epistemologiske uskyld, som Stephen Greenblatt udtrykker det. Spørgsmålet om ubestemmelighed er således stadigvak af vital betydning. Argeligt at Dahlerup ikke har villet tage dette spørgsmål op til behandling. Det ville samtidig have givet hende en anledning til at foretage en skarpere sondring mellem den dekonstruktive og den nykritiske nærlæsning. For ubestemmelighed betyder vel og marke ikke tvetydighed eller polysemi i nykritisk forstand. Bag nykritikkens fremhævelse af tekstens komplekse flertydighed ligger forestillingen om den gode litteraturs uudtømmmelige betydningsrigdom. Den dekonstruktive kritik deler ikke denne forestilling. Ubestemmelighed vidner om sprogets upålidelige epistemologiske status og dermed om tekstens manglende evne til at opfylde sit eget formål.

Dahlerup lader sig ikke nøje med at referere andres teorier og meninger. Hun har selv en mening om det hele, fra Derridas skriftbegreb til de Mans ungdomsjournalistik. Den personlige tone præger ogsð̊ bogens sidste kapitel, der handler om feministisk dekonstruktion, men her virker den ikke anmassende. Man mærker, at Dahlcrup har et langt bedre overblik over denne del af stoffet, $o g$ det giver hele fremstillingen et løft. Som i kapitlet om læseren præsenteres en lang række teoretikere og kritikere, men uden at overblikket tabes. Så kan man selvfølgelig altid diskutere udvalget af navne. Dahlerup har valgt at lægge hovedvægten på de franske teortikere Kristeva, Cixous og Irigaray, mens den amerikanske feministiske dekonstruktion repræsenteres af Teresa de Lauretis og Nancy Miller. Jeg savner her navne som Shoshana Felman, Gayatri Spivak, Jane Gallop og Mary Jacobus.

Kendetegnende for feministisk dekonstruktion er, sat den flytter interessen fra kvindeforskning til kønsforskning, fra empiri til teori og fra virkelighed til semiotik « (71). Dahlerup understreger i sin gennemgang perspektiverne i dette skred, men fastholder samtidig, at alliancen mellem dekonstruktion og feminisme ikke er uproblematisk. Kapitlet kan læses som et glimrende diskussionsoplag, men er samtidig mere end det. Her, som i resten af bogen, er hensigten at gøre teorierne analytisk brugbare. Kapitlet munder ud i en læsning af et uddrag af Lyschanders Billesliegtens Rimkrønike. Analysen af Lyschander er bogens længste og mest vellykkede. Ikke blot fordi den klart demonstrerer, hvad en dekonstruktiv feministisk læsning »kan« i forhold til en mere traditionel feministisk interpretation, men først og fremmest fordi analysen ikke bare har karakter af sanvendt teori «, men selv tanker teoretisk over forholdet mellem køn og repræsentation. Her er der inspiration at hente.

Der er næp tvivl om, at Dekonstruktion. 90' ernes litteraturteori falder pá et tørt sted. Mange (lærere og stude- 
rende) har sikkert sukket efter en hurtiglæst og letfattelig indføring i dekonstruktion. Man kan kun glæde sig over, at Gyldendals Intro-serie nu har gjort en sådan publikation mulig; jeg tvivler ikke på, at den vil blive flittigt brugt. Støørst appel vil bogen formentlig have til (litteratur)studerende $\mathrm{p} a ̊$ universitetes grunduddannnelse. Som en forste introduktion til den litterære dekonstruktion kan bogen da også anbefales. Men skal den bruges $i$ undervisningen på universitetsniveau, bør dens fremstilling af dekonstruktion nok suppleres med mere dybtgående introduktioner og allerhelst, naturligvis, med de dekonstruktive kritikeres egne tekster.

\section{Noter}

1. Jan Rosiek, »Allegori, retorik og bogstavets tavshed. Paul de Mans dekonstruktion « i Litteratur \& samfund 46 (1990) p. 69.

2. Se Robert Moynihan, A Recent Imagining. Interviews with Harold Bloom, Geoffrey Hatman, J. Hillis Miller, Paul de Man, 1986, p. 148.

\section{Anne-Louise Sommer}

\section{Kracauer}

Henrik Reeh: Storbyens Ornamenter Siegfried Kracauer og den moderne bykultur, Odense University Studies in Literature, vol. 28, Odense Universitetsforlag, 275 sider, illustr. 1991.

Som det indledningsvis bemærkes indskriver Storbyens Ornamenter sig i et støre projekt, hvis ærinde er etableringen af en humanistisk urbanvidenskab. Herved forståes en tværfaglig praksis, hvor byen søges afdækket som ramme for bevidsthedsmæssige, kulturelle og sociale processer af generaliseret karakter.

Byen og byrummet er gennem de senere år blevet gjort til genstand for en stadig stigende opmærksomhed, spændende fra arkitekternes kritik og videreudvikling af tidligere tiders byplanlægning og urbanbygnings typologier, over den administrativt teknologiske sektors fors $\emptyset \mathrm{g}$ pa forståelse og beherskelse af byens komplekse strukturer, til kunsthistorikere og litteraters orientering mod byens tematiske og motiviske rolle i den kunstneriske fremstilling. Fælles for denne optagethed af byen er dels ønsket om - og viljen til - at oparbejde en analysepraksis hinsides de traditionelt opdelte akademiske/vidensmæssige afgrænsninger og grupperinger; og dels artikuleringen af selve bytematikken i dialogisk relation til en begrebsafklarende forholden sig til det moderne.

Igennem analyser af den tyske intellektuelle Siegfried Kracauers urbanskrifter fra mellemkrigsårene - og med 